\title{
Biblioteca pública e identidade: percepções intersubjetivas enraizadas em torno da Luiz de Bessa ${ }^{1}$
}

\author{
Fabrício José Nascimento da Silveira
}

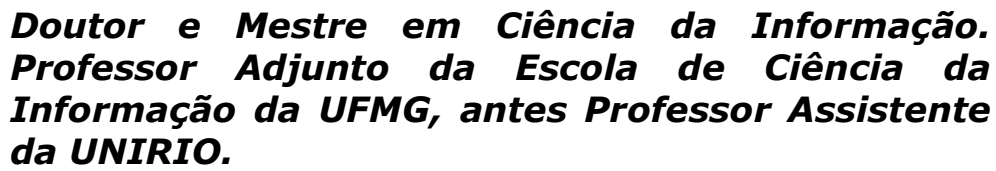

http://dx.doi.org/10.1590/1981-5344/2283

Este artigo tem por objetivo discutir sobre a participação das bibliotecas públicas no processo de elaboração intersubjetiva de referenciais identitários, tendo como aportes teóricos os conceitos de identidade e enraizamento. Para tanto, adota-se por premissa que a identidade se dá a ver como um discurso em permanente elaboração, expresso e potencializado através do contato com o outro nas inúmeras esferas de socialização que fomentam a existência de uma coletividade, dinâmica estimulada, também, pelas bibliotecas públicas, em virtude do estatuto representacional que atravessa seus acervos, serviços e setores. Proposições confirmadas por meio da análise das histórias de vida de dois usuários da Biblioteca Pública Estadual Luiz de Bessa. Ao evidenciarem nos depoimentos os distintos pontos de ancoragem que sustentam suas referências interpessoais e a importância da Luiz de Bessa - dimensões simbólicas, afetivas e estruturais - ao longo desse processo formativo, as narrativas erigidas pelos depoentes revelam que a Biblioteca se posta como lugar de enraizamento para os discursos identitários por eles forjados.

Palavras-chave: Biblioteca Pública. Identidade. Enraizamento. Histórias de vida. Biblioteca Pública Estadual Luiz de Bessa.

Este trabalho sintetiza alguns dos resultados de minha tese de doutoramento defendida junto ao PPGCI/UFMG, sob orientação da Profa. Dra. Alcenir Soares dos Reis, a quem agradeço pelo carinho, amizade e todos os ensinamentos a mim dispensados. 


\section{Public library and identity: perceptions intersubjectives anchor in the Luiz de Bessa}

The aim of this essay is to discuss the participation of public libraries in the intersubjective development process of identity references. It was tailored as theoretical framework the concepts of identity and rootedness. For such, adopt as a premise that identity is to be seen as a discourse in constant development, expressed and enhanced through the contact with each other in many spheres of socialization that ensure the existence of a collectivity, stimulated dynamic, also by public libraries because of the representational status that crosses their collections and services sectors. The propositions were confirmed by the analysis of the life stories of two users of the library "Biblioteca Pública Estadual Luiz de Bessa". Evidencing in the statements the different anchor points that support their interpersonal references and the importance of Luiz de Bessa - symbolic dimensions, affective and structural - throughout this formative process, the narratives erected by the deponents reveal that the Library exerts a force of impregnating on their individual biographies and put itself as a place of rooting of the identity discourses forged by them.

Keywords: Public Library. Identity. Rooting. Life Stories. State Public Library Luiz de Bessa.

Recebido em 24.11.2014 Aceito em 25.11.2014

\section{Introdução}

O que é e qual é a importância social/cultural das bibliotecas públicas no século XXI? Assim formuladas, as questões norteadoras do seminário A biblioteca pública no século XXI: lugar social, atuação política e estratégias de mobilização cultural acenam para dois enquadramentos analíticos distintos: o primeiro deles liga-se à possibilidade de pensarmos as mudanças e transformações que, em seu conjunto, realocam as atividades, serviços e funções tradicionalmente apontadas como específicas de tais instituições em face de uma nova conjuntura histórica, o século XXI.

Por outro lado, em tempos de revolução midiática, onde o acesso remoto à informação e o deslumbramento com os dispositivos 
tecnológicos de mediação comunicacional ganham acentuado relevo, as duas questões acima apresentadas poderiam, ainda, serem acionadas por certos sujeitos para se questionar o lugar e a importância social/cultural das bibliotecas públicas na atualidade. Desconsiderando a historicidade de tais instituições e sua especificidade no âmbito dos distintos sistemas de produção, recuperação, organização, preservação e disseminação da informação, tais questionamentos recorrentemente colocam em suspeição o conjunto de fatores incorporados como justificativa para se empregar "vultosas receitas financeiras" em sua dinamização, bem como ampliar a formação de profissionais especializados para atuar nessas unidades informacionais. Outro ponto contestado por tais críticos das bibliotecas públicas coloca em cheque se haveria mesmo uma demanda significativa em torno de seus serviços, da utilização de seus espaços e acervos em um mundo amplamente globalizado e interconectado remotamente.

Ora, sabemos que as bibliotecas públicas surgem em um contexto histórico bem demarcado: a Inglaterra pós-Revolução Industrial e que sua função primária era servir de refúgio a uma parcela da população posta à margem de outros mecanismos culturais em função da disparidade econômica causada, sobretudo, pela intensificação dos fluxos migratórios que traziam o homem do campo para as malhas urbanas da cidade. Já àquela época, esperava-se que elas contribuíssem de maneira significativa para a "ordem social" e o "progresso da nação", bem como para a "manutenção da democracia" instaurada após a laicização dos Estados Nacionais. Ordem, progresso e manutenção dos referenciais democráticos que deveriam ser dinamizados, em um primeiro plano, por ações relacionadas à leitura e à educação. Razões pelas quais foram visualizadas de imediato como um "bom investimento social".

Sua defesa, conforme atesta Susana Mueller (1984, p. 9), ressaltava o baixo custo de um empreendimento que permitiria dar ao povo acesso à "boa literatura", fazendo das bibliotecas públicas o meio mais econômico de se tentar manter homens exaustos e sem dinheiro entretidos em prazeres "inocentes", e, portanto, fora das prisões, tribunais e asilos. Além disso, acreditava-se que as bibliotecas públicas poderiam provocar em seus usuários o hábito e o gosto pela "boa leitura", dando, assim, continuidade ao "trabalho civilizatório" iniciado pela escola primária.

Posteriormente, e para além dos ideários positivistas de ordem e progresso, de boa leitura e de trabalho civilizatório que definiram seus primeiros contornos, percebeu-se que as bibliotecas públicas poderiam contribuir para a socialização de seus usuários e para sua individualização, seja através da preservação e transmissão dos insumos representacionais da cultura de grupos específicos, seja pela promoção da vida intelectual dos indivíduos e lugares onde se inseriam. Com isso, a definição de seus atributos e funções sociais passou a ser estruturada "pelo uso feito da informação registrada e pela importância desta na vida das pessoas". (MUELLER, 1984, p. 25). Nesses termos, uma vez que tal valor de uso muda e evolui, tal como se transformam os hábitos informacionais e os sistemas sociais nos quais os mesmos se assentam, as expectativas em 
relação às bibliotecas públicas também estão sujeitas a deslocamentos e revisões.

Expectativas em relação às bibliotecas públicas no século XXI, eis o que, em seu cerne, o seminário visou discutir. No caso específico da mesa Biblioteca pública: memória, identidade e mediação cultural, tais expectativas tiveram como ponto de convergência os domínios da memória, da identidade e da mediação cultural. Biblioteca e memória, dos três eixos em relevo, este talvez seja o que possua suas fronteiras melhor definidas. Isto porque, a célebre expressão de Pierre Nora, Lieux de Memóire, pode ser claramente empregada para definir uma biblioteca pública, não apenas por sua função de preservar e disseminar insumos informacionais, mas também por sua dimensão material, cujos contornos corporificam as ansiedades e necessidades específicas de uma dada coletividade. Nessa mesma mirada, não se pode esquecer a dimensão simbólica que atravessa tais lugares e que acaba por retratar experiências reais ou imaginadas levadas a cabo por sujeitos fundantes de variados graus de interação com o espaço, o acervo e também com outros usuários de cada uma destas instituições.

Por seu turno, a questão da mediação cultural, especialmente via atividades de leitura, há muito se constitui como diretriz que deve florescer no interior e para além dos limites da biblioteca pública. Isto porque, conforme Martins (2010, p. 211), por meio das ações de mediação "os atores em inter-relação e situados em campos históricoculturais de conflito e contradição, negociam, disputam e confrontam sentidos simbólicos destinados à leitura, apreensão, nomeação e significação do real". Em outros termos, ao intermediar o contato entre os sujeitos e os diferentes códigos, sentidos e universos simbólicos que perpassam a realidade concreta de suas vidas, as bibliotecas públicas propiciam a cada agente inscrito neste processo, que é interacional por natureza, a capacidade de dilatar as compreensões que possuem do mundo e de si mesmos.

Mas e a questão da identidade? Considerando-se a fluidez do conceito e a impossibilidade da demarcação concreta de uma identidade, como podemos aproximá-la das bibliotecas públicas? Um dos caminhos possíveis implica considerar a trajetória temporal de consolidação do conceito e sua demarcação teórica. Isso demanda adotar perspectivas que tratem a identidade como um constructo intersubjetivo imerso no âmbito de práticas sociais tangenciadas por questões de linguagem e por demandas culturais, históricas e políticas específicas. Eis o que pretendemos fazer aqui lançando mão da seguinte estratégia analítica: avaliar qual o lugar simbólico e afetivo dispensado à biblioteca pública, em particular à Biblioteca Pública Estadual Luiz de Bessa, nas memórias e histórias de vida de dois de seus usuários. Para tanto, comecemos pelas formulações teóricas. 


\section{Identidade e enraizamento: a problemática da definição}

Falar sobre identidade e produção de referenciais identitários no mundo contemporâneo implica adotar por prerrogativa a ideia de que talvez a marca mais eminente da conjuntura sócio-histórica atual seja a fragmentação. Isto porque, se até o início do século $X X$ os sujeitos eram "identificados" a partir de enquadramentos políticos, sociais, sexuais, econômicos e culturais estáveis, as mudanças produzidas pela globalização imprimiram novas configurações para as muitas esferas de sociabilidade com as quais se tornou possível interagir. Com isso, segundo Stuart Hall (2001, p. 7), as velhas identidades que por tanto tempo estabilizaram a vida social entraram em declínio, fazendo surgir novas identidades e fragmentando o indivíduo moderno, até aqui visto como um sujeito unificado.

Pensada até aquele momento como uma imagem vinculada à ideia de originalidade, de semelhança, de algo que costura e mantém a unidade, o indivíduo globalizado passa a designar a identidade como um discurso em permanente processo de elaboração. Ela "nos é revelada como algo a ser inventado, e não descoberto; como alvo de um esforço, "um objetivo"; como uma coisa que ainda se precisa construir a partir do zero ou escolher entre alternativas e então lutar por ela e protegê-la lutando ainda mais" (BAUMAN, 2005, p. 21-22), ou seja, como uma produção que nunca se completa, formada e transformada no interior das representações. Representações que, por sua vez, se forjam através do prisma da multiplicidade, da urdidura dos diversos discursos e práticas simbólicas que nos posicionam no mundo, que dizem nosso lugar em relação ao outro - outros pontos de referência, outros portos de ancoragem. Sendo assim, as referências e marcadores identitários passam a serem organizados relacionalmente em um "jogo de posicionamentos, de deslocamentos entre sujeitos que vivem num mundo, falam num mundo e, nesse falar, se reposicionam continuamente". (FRANÇA, 2002, p. 38).

Mudança de percepção que vincula nossas representações identitárias à idéia de projeto, de algo que se encontra sempre em construção. Com isso, a crença de que a identidade seria formada por associação a códigos simbólicos supostamente estáveis, homogêneos, coesos e unificados também se dissolve. Portanto, enquanto elaborações estruturadas discursiva e relacionalmente, nossos enquadramentos identitários não se manifestam tendo como única referência a identificação das semelhanças, visto instituírem, neste mesmo movimento, a construção da diferença e da distinção. Sendo assim, tentar idealizar um discurso representacional para si e para o outro que seja único, coeso e completo em si mesmo torna-se, na atual conjuntura histórica, uma fantasia, uma vez que nos tornamos capazes de assumir, através de nossos posicionamentos, identidades múltiplas nos diversos momentos e espaços aonde nossa vida e nossas ações sobre o mundo adquirem 
sentido e encontram ressonâncias. Razão pela qual se faz necessário esclarecer, já neste momento, que:

O conceito de identidade aqui desenvolvido não é, portanto, um conceito essencialista, mas um conceito estratégico e posicional. Isto é, de forma diretamente contrária àquilo que parece ser sua carreira semântica oficial, esta concepção de identidade não assinala aquele núcleo estável do eu que passa, do início ao fim, sem qualquer mudança, por todas as vicissitudes da história. Esta concepção não tem como referência aquele segmento do eu que permanece, sempre e já, "o mesmo", idêntico a si mesmo ao longo do tempo. Ela tão pouco se refere, se pensarmos agora na questão da identidade cultural, àquele eu coletivo e verdadeiro que se esconde dentro de muitos outros eus - mais superficiais ou mais artificialmente impostos - que um povo, com uma história e uma ancestralidade compartilhadas, mantém em comum. Ou seja, um eu coletivo capaz de estabilizar, fixar ou garantir o pertencimento cultural ou uma "unidade" imutável que se sobrepõe a todas as outras diferenças - supostamente superficiais. Essa concepção aceita que as identidades não são nunca unificadas; que elas são, na modernidade tardia, cada vez mais fragmentadas e fraturadas, que elas não são, nunca, singulares, mas multiplamente construídas ao longo de discursos, práticas e posições que podem se cruzar ou serem antagônicas. (HALL, 2008, p. 108, destaques do autor).

Destacar que nossas referências identitárias são construídas dentro e não fora do discurso e que as mesmas não são um dado fixo, coerente, estável e permanente é importante porque nos possibilita apreender o quanto estão ligadas aos recursos que utilizamos para nos posicionar frente ao outro e no mundo. Razão pela qual acreditamos que só se torna possível falar em identidade se os matizes que a compõem forem concebidos como amálgamas provenientes do entrelaçamento de representações simbólicas demasiadamente amplas que em momento algum devem ser interpretadas como se possuíssem apenas um sentido.

Ponderações que nos auxiliam a assimilar que o movimento de constituição de referenciais identitários acaba por refletir menos o que nós somos (estado), e mais o que nos tornamos (processo). Servem, também, como um indicativo de que essa constituição se dá sempre de maneira coletiva e relacional, o que equivale a dizer que a identidade emerge não tanto de um centro interior, de um eu verdadeiro e único, mas do diálogo entre os conceitos, definições e práticas apresentadas para nós pelos discursos de uma cultura e pelo nosso desejo (consciente ou inconsciente) de responder aos apelos feitos por estes significados, de sermos interpelados por eles, de assumirmos ou contestarmos as posições de sujeito formuladas por nós e para nós. Além disso, colocam em 
contraponto o potencial orientador que os processos de socialização primária, aqueles a partir dos quais constituímos nossos laços de enraizamento - os índices de simbolização que apreendemos junto à família, à escola, à igreja, por exemplo - exercem sobre nós no momento em que somos chamados a nos posicionarmos frente a determinado discurso representacional. Sendo assim, e conforme atesta Stuart Hall:

O que denominamos "nossas identidades" poderia provavelmente ser melhor conceituado como as sedimentações através do tempo daquelas diferentes identificações ou posições que adotamos e procuramos "viver", como se viessem de dentro, mas que, sem dúvida, são ocasionadas por um conjunto especial de circunstâncias, sentimentos, histórias e experiências única e particularmente nossas, como sujeitos individuais. Nossas identidades são, em resumo, formadas culturalmente. (HALL, 1997, p. 26-27).

São formadas culturalmente e ancoradas em inúmeras práticas, discursos e esferas da vida social - a família, a escola, a igreja, os sindicatos, o trabalho, o partido político e também as bibliotecas. A identidade é, pois, uma subjetivação ancorada em uma estrutura representacional que se dá a ver, que se expressa por meio de alguma forma de objetivação ${ }^{2}$. Razão pela qual, por mais fluida e maleável que possa parecer, requer sempre um ponto de referenciação, uma possibilidade de enraizamento.

Enraizamento, eis outro conceito/operador analítico de grande valor para apreendermos de maneira mais clara os pontos de interconexão e as modalidades de subjetivação que fazem das bibliotecas públicas um lugar de ancoragem, um pólo produtor de discursos identitários. Formulada por Simone Weil, escritora, mística e filósofa francesa, a noção de enraizamento expressa uma forma de estar no mundo. Diz de um conjunto de atividades e experiências de subjetivação que conferem estabilidade e sentido à interação coletiva, bem como às marcas de individualidade que atravessam cada sujeito. Desta feita, os "seres" enraizados são aqueles que enriquecem as práticas da comunidade e fortalecem suas raízes. Que participam de grupos cuja herança do passado alimenta a gramática simbólica moduladora de uma dada noção de cultura. Uma cultura que impede a desagregação dos cidadãos e a paralisia do conhecimento. Em síntese, o que aqui se denomina de enraizamento refere-se ao conjunto de experiências intersubjetivas e de

\footnotetext{
${ }^{2}$ Ancoragem e objetivação são dois conceitos desenvolvidos pelo campo da psicologia social, mais notadamente no âmbito dos estudos acerca das representações sociais. O primeiro indica um exercício de associação em que grupos e sujeitos estabelecem uma relação de proximidade entre aquilo que ainda não está classificado, nem rotulado com imagens, categorias e explicações já conhecidas e aceitas socialmente. Trata-se, pois, de um movimento de categorização das coisas do mundo a partir de configurações simbólicas enraizadas em nossa memória social e subjetiva. A objetivação, por sua vez, refere-se ao ato de transformar a associação abstrata inferida durante o processo de ancoragem em algo quase físico. Em termos representacionais, a objetivação denomina o ato de atribuir/descobrir o aspecto icônico de uma determinada ideia.
} 
ações concretas que buscam recriar o mundo através de práticas sociais transformadoras. Talvez por isso a pensadora tenha afirmado que:

O ser humano tem uma raiz por sua participação real, ativa e natural na existência de uma coletividade que conserva vivos certos tesouros do passado e certos pressentimentos do futuro. Participação natural, isto é, que vem automaticamente do lugar, do nascimento, da profissão, do ambiente. Cada ser humano precisa ter múltiplas raízes. (WEIL, 1996, p. 411).

É, pois, este diálogo entre passado e futuro que faz com que a comunidade não perca suas raízes, ao mesmo tempo em que faculta estabilidade e sentido à vida e às ações das pessoas. Isto porque, o enraizamento pressupõe a participação ativa de um indivíduo entre outros agentes sociais em condições bastante específicas. Condições que podem vir do seio familiar, da escola, do trabalho, da integração à vida religiosa, da cidade, da biblioteca. Onde há enraizamento, a socialização constitui o substrato no qual cada sujeito em particular recebe os princípios da vida moral, intelectual e espiritual que irá nutrir sua existência individual e coletiva. Para tanto, faz-se necessário observar que:

Esta comunicação com o passado não consiste em uma atitude meramente contemplativa. Tampouco assume uma orientação reacionária. Onde os homens espraiam raízes, as lutas e construções dos antepassados, suas ideias e tradições, alicerçam realizações que, por sua vez, irão revesti-las de novos significados. Não se trata de uma importação passiva do mundo pregresso. (FROCHTENGARTEN, 2005, p. 12).

Nesse sentido, promover o enraizamento não pressupõe isolar um meio social de suas influências externas. Ao contrário, os contatos e as trocas de influências são necessários ao processo de criação de vínculos desde que esse intercâmbio propicie o reconhecimento de uma parte em relação à outra e estimule o respeito à originalidade e à individualidade dos envolvidos. Nas palavras de Frochtengarten (2005, p. 13): "em grupos que promovem o enraizamento, estão preservadas as condições de igualdade que garantem aos homens o livre exercício da palavra e de novas fundações: sua aparição diante de outros homens revela sua identidade pessoal e singular".

Portanto, o sujeito enraizado não pode prescindir da socialização, já que é por meio da aparição pública, do diálogo estabelecido com o outro na esfera pública que ele traça e elabora as marcas de uma imagem delineada de si e do outro. Talvez por isso Ecléa Bosi (2013, p. 196) nos lembre que "enraizar-se é um direito fundamental do ser humano e a negação a esse direito tem consequências graves para a cultura e a vida em sociedade". 
Constatação que nos leva, mais uma vez, à questão que orienta toda a nossa discussão, a saber: como podemos aproximar o conceito de identidade do universo das bibliotecas públicas? Tais instituições são mesmo instâncias de produção, preservação e socialização de discursos identitários enraizados? Buscamos responder a tais indagações lançando mão dos testemunhos de dois usuários da Biblioteca Pública Estadual Luiz de Bessa. Mais especificamente, da história de vida de um sujeito cuja formação enquanto leitor se deve às atividades extensionistas do carro biblioteca mantido por essa instituição, e de um segundo sujeito, este um usuário "baixa-visão" que teve as relações mantidas com o mundo e a imagem de si completamente alteradas após começar a frequentar o setor braile da Luiz de Bessa.

\section{A Biblioteca Pública Estadual Luiz de Bessa: um lugar de ancoragem e de enraizamento identitário}

Fundada em Belo Horizonte no ano de 1954 por meio da Lei Estadual no. 1087, sancionada em 2 de junho por Juscelino Kubitschek, a Biblioteca Pública Estadual Luiz de Bessa possui por função primária servir de centro de memória da capital mineira, reunindo, preservando e divulgando os registros da história local, de modo a valorizar a identidade cultural belohorizontina, se reportando, de modo mais geral, ao universo simbólico de todo o Estado. Está localizada em uma das regiões mais nobres da cidade e recebe cerca de 390 mil usuários por ano, aos quais presta uma série de serviços: empréstimo domiciliar, sala de estudos e leitura, carro-biblioteca, um setor especializado em acolher deficientes visuais, uma sucursal destinada ao público infanto-juvenil e também o serviço de caixa-estante que leva livros e a oportunidade de leitura a creches, asilos, prisões e espaços alternativos muito diferentes de suas fronteiras.

Tornou-se a responsável por manter coleções raras e de grande valor para o estudo, a divulgação e a representação da história e do "modo de vida mineiro". Em seu acervo destacam-se a Coleção Mineiriana3; a Coleção Rita Adelaide ${ }^{4}$ e os jornais e revistas que pertenceram à Hemeroteca Pública de Minas Gerais, hoje incorporados ao patrimônio documental da Luiz de Bessa.

Ao longo de seus 60 (sessenta) anos de atuação, inúmeros usuários se formaram como leitores tendo por referência as coleções, atividades e o espaço de sociabilidade que se criou no perímetro de suas

\footnotetext{
${ }^{3}$ Criada através do Decreto no. 11.996, de 05/08/1969 por uma comissão de intelectuais mineiros, a Coleção Mineiriana tem por finalidade compor um acervo de obras sobre Minas Gerais, sua história, letras, artes, ciências da terra e do homem, bem como desenvolver ações de divulgação da cultura do estado, editar e promover publicações de obras relacionadas ao tema e formar a memória audiovisual de Minas. Foi tentando dinamizar essas ações que, em 03/02/1970, o governo do Estado sancionou o Decreto nº. 14.314 , instituindo a obrigatoriedade de se processar a remessa de publicações oficiais à biblioteca Luiz de Bessa para serem incorporados à coleção.

${ }^{4}$ Composta por 1.305 volumes representa a biblioteca pessoal do jurista e bibliófilo Tancredo Martins e recebeu este nome em homenagem à sua mãe. Destaca-se por seu conteúdo, raridade, beleza e singularidade das encadernações, ilustrações e iluminuras. Os títulos tratam principalmente de religião, literatura, história, filologia e obras de referência. Também figuram no acervo livros sobre artes, botânica e geografia.
} 
dependências. Em virtude disso, ocupa hoje um lugar privilegiado na vida e na memória de diversos sujeitos, congregando em torno de si um universo de representações simbólicas multivariadas que, em um plano mais geral, fomenta a mobilização de diversos quadros de sentido cuja síntese ampara e dá a ver a formulação de um discurso identitário intersubjetivo em estreito diálogo com experiências objetivadas e enraizadas no plano coletivo. Formulações que serão evidenciadas através dos testemunhos de dois usuários cujas histórias de vida mostram-se profundamente marcadas pelas relações mantidas com a biblioteca - seu espaço físico, acervos e atividades - e com os demais sujeitos responsáveis por sua dinamização e funcionalidade - profissionais e demais frequentadores da instituição.

O primeiro depoente chama-se José J. e nasceu em 25/09/1969, na cidade de Pitangui. Mudou-se para Belo Horizonte quando tinha dois anos de idade, veio com os pais e seus oito irmãos. Residiram em uma casa pequena em um dos bairros periféricos da zona oeste da cidade. Hoje é casado, pai de duas meninas e tornou-se professor universitário em duas faculdades da capital, uma pública e outra particular. É também escritor, coordenador de projetos culturais e durante vários anos integrou a Comissão Municipal de Incentivo à Cultura, tendo sido ainda Consultor da UNESCO para políticas públicas.

Relata que os pais nunca tiveram acesso à leitura, mas que sempre se esforçaram para que os filhos estudassem. Sempre foi aluno de escolas públicas e diz se lembrar da existência de bibliotecas escolares, mas não alimenta boas recordações desses espaços, principalmente em relação aos bibliotecários, "eles pareciam que queriam guardar os livros em uma redoma né, tipo assim: - larga o livro menino e tudo mais". (JOSÉ J. apud SILVEIRA, 2014, p. 1).

Os poucos livros existentes em casa eram de seu irmão mais velho, "ele comprava aquelas coleções da Abril e ia fazendo a coleção, montando livros, aquelas coisas assim de... é... literatura universal, literatura brasileira e aos poucos eu fui lendo vários desses livros né!". (JOSÉ J. apud SILVEIRA, 2014, p. 1). Contudo, afirma categoricamente que o elemento que mais influenciou sua formação enquanto leitor foi a descoberta, na $5^{a}$ série, do "caminhão-biblioteca" da Luiz de Bessa:

A experiência com a literatura efetiva veio somente a partir dessa possibilidade que apareceu quando a mulher do caminhão-biblioteca chegou na minha escola falando - "quem quiser pode fazer a carteirinha do caminhão-biblioteca, tá na praça da igreja de Salgado Filho" - e aí ficou 2 meses, a mulher ficou 2 meses. Ela subia com todo mundo né... com aquelas criaturas pequenas pra gente ir lá na praça da igreja do Salgado Filho pra pegar os livros". (JOSÉ J. apud SILVEIRA, 2014, p. 1-2).

O primeiro livro que leu foi "As vinhas da Ira", do John Steinbeck, 
Apanhei igual cachorro do livro, mas foi muito particular aquela leitura, porque como eram clássicos eu não entendia muito (risos) na época não. Então eu lia por... por interesse porque eu achava bacana, legal mas eu não... pra mim aquilo era como se eu tivesse descortinando o mundo que eu não fazia idéia que existia". (JOSÉ J. apud SILVEIRA, 2014, p. 3).

Diz que sempre foi muito "caxias" na escola e tímido também. Comportamento que acredita estar relacionado a uma lembrança da $3^{a}$ série: "uma professora botou esparadrapo, fita na minha boca, disse que eu falava demais, então eu tive um trauma da quarta até a quinta série. Aí o encontro com os livros me ajudou a me expressar melhor e a quebrar esse trauma". (JOSÉ J. apud SILVEIRA, 2014, p. 3).

Quando adolescente, não frequentava os espaços urbanos da cidade, "a minha família não tinha condições de ir a lugar nenhum". (JOSÉ J. apud SILVEIRA, 2014, p. 4). A recordação mais viva que permanece é de ter ido com a irmã em uma feira de livros e de ter ganhado de presente a obra "Marcelo, Marmelo, Martelo", "esse livro rasgou minha... rasgou minha... rasgou minha vida de criança". (JOSÉ J. apud SILVEIRA, 2014 , p. 4). O depoente ainda o preserva consigo até hoje, ou melhor, segundo ele, "suas filhas têm esse livro hoje né!".

A Praça da Liberdade aparece em seu depoimento como um lugar de elite, que o constrangia, assim como outros territórios de Belo Horizonte, notadamente em função de sua condição financeira. Perspectiva que também inclui o prédio da Luiz de Bessa: "eu não gostava do ambiente da Luiz de Bessa. O lugar não me..., não me deixava muito..., muito tranquilo". (JOSÉ J. apud SILVEIRA, 2014, p. 5). Sendo assim, o seu contato com a Biblioteca se deu, de maneira mais efetiva, através do carro-biblioteca, relação que manteve por 4 anos e meio, da $5^{a}$ série até o $1^{0}$ ano do Cefet, tendo sido ampliada anos depois, em função de seu trabalho como consultor de políticas públicas, inclusive com o prédio e o acervo da Praça da Liberdade.

Chegou até lá incentivado pela namorada, mas diz que achou o ambiente estranho, era "maravilhoso demais para quem vinha da periferia", e sempre preferiu a intimidade, a sensação de acolhimento que experimentara no "caminhão-biblioteca":

O lugar não me..., não me deixava muito..., muito tranqüilo. E eu me lembro como foi! É...., eu tava..., eu já tava fazendo faculdade e eu me lembro de ter vindo uma..., acho que numa sexta-feira na Praça da Liberdade. Eu tinha feito a carteirinha, novinha, porque assim, eu tenho a carteirinha ainda lá em casa, eu peguei dois, dois únicos livros, porque pra mim era muito fora de mão vir a biblioteca. E eu me lembro que eu vim, vim numa sexta-feira, várias sextas-feiras e aí eu passei mais ou menos uns dois ou três meses vindo sextas-feiras regularmente à biblioteca Luiz de Bessa, foi acho que só... eu acho que só... só aqueles dois, três meses que eu tive contato 
com a biblioteca, mesmo. Mas eu não gostava muito daquele ambiente assim de... "será que alguém vai me bater?", sabe assim? Eu achava aquilo meio estranho, era um pouco assim a minha sensação. O prédio eu sempre achei maravilhoso, até demais, pra quem era da periferia, que é a sensação que eu tinha desde... desde pequeno. (JOSÉ J. apud SILVEIRA, 2014, p. 5).

Percepção que, por muitos anos, fomentou em nosso depoente a sensação de que a Luiz de Bessa era um lugar de elite que talvez não tenha sido "feito para as pessoas, para as pessoas se sentirem bem, se sentirem confortáveis, tranqüilas", (JOSÉ J. apud SILVEIRA, 2014, p. 15). Filho de uma família humilde e morador da periferia de Belo Horizonte, José J. se sentia constrangido com o tamanho e a limpeza da Biblioteca, por que?

Porque eu..., sei lá..., o tipo de..., eu sempre tive, por exemplo, no Palácio das Artes eu tinha dificuldade de entrar, porque eu era uma criatura de periferia, eu tinha uma casa desse tamanhozinho e o lugar era grande. E um lugar grande me deixava sem graça. Na minha casa aquele monte de gente, então, assim..., não era pela quantidade de gente, é porque o lugar, o tamanho do lugar me deixava assustado e aquilo me deixava assim, meio..., eu tinha aquela sensação de que alguém ia me falar que eu não podia fazer alguma coisa (risos), sabe? Aquele pedacinho ali da entrada ${ }^{5} \ldots$, aquele pedaço era uma tortura pra mim (risos). Era como se eu atravessasse e, tipo assim, será que tem alguém olhando, será que tem... então, esse lugar meio oco não me ajudava muito não. (JOSÉ J. apud SILVEIRA, 2014, p. 6-7).

Um "lugar meio oco" que encontra seu oposto no carro-biblioteca ou, "caminhão-biblioteca" como o mesmo prefere dizer. Espaço que the ajudou a redimensionar suas perspectivas de vida e, posteriormente, a estabelecer outros vínculos com aquela instituição. Mas qual a diferença de um espaço para outro? O carro-biblioteca não é um representante da própria Luiz de Bessa? Deixemos que o próprio entrevistado nos explique as nuances dessa diferença:

Porque eu saia da escada e já caía direto nos livros. (risos). A criatura [a bibliotecária] sabia o tipo de livro que eu gostava, ela me tratava por você, ela era perfeitamente prosa, era como se ela fosse da minha casa. Por exemplo, eu lembro um

\footnotetext{
${ }^{5}$ Menção ao espaço de entrada da Biblioteca Luiz de Bessa. O espaço da porta de entrada até a recepção dos usuários.
} 
dia que ela me apresentou "A carta roubada do Edgar Alan Poe", e me apresentou com altas recomendações falando assim: "agora que você acabou de ler todos os livros de Agatha Christie, você vai ler a carta roubada; esse autor aqui você vai achar o máximo" (risos), então essa proximidade e o fato de o espaço ser menor, me deixava menos constrangido, não é só o fato de eu ir junto com os meus colegas, ate porque nos últimos, no último um ano e meio, eu ia praticamente sozinho, era só eu, o caminhão-biblioteca deixou de ir pra lá porque tinha pouca gente indo, então eu ia praticamente sozinho pro caminhão-biblioteca. É..., mas a diferença do lugar, essa coisa vasta, toda grande, toda imensa, e aquele lugar onde eu... eu me sentia menos constrangido. [...] Eu me lembro que essa relação foi muito importante pra eu me aproximar de um professor que depois foi diretor do Cefet. A experiência com o caminhão-biblioteca foi tão significativa na minha vida porque nele eu podia entrar, olhar os livros que eu quisesse... Se eu pudesse eu teria um caminhão-biblioteca dentro da minha casa (risos). Então, não foi dentro do ambiente da biblioteca publica, mas foi reflexo direto da experiência com o caminhão-biblioteca, porque aquilo impactou muito na minha experiência né! $E$ pensar que aquelas pessoas deixavam as casas delas e iam lá pra chegar até mim, foi então que eu me toquei que eu teria que ir até à biblioteca. (JOSÉ J. apud SILVEIRA, 2014, p. 8-9).

$E$ foi, não só porque se tornou professor e pesquisador acadêmico ou um consultor para políticas públicas, mas porque a relação com 0 carro-biblioteca acabou por se reverberar em outros campos de sua vida.

E essa relação que.., que depois eu recuperei é que me faz entrar hoje com um certo grau de tranqüilidade naquele lugar e tudo mais, exatamente porque o meu caminho foi diferente de outras pessoas com a biblioteca, eu não morava por aqui, eu morava em outro lugar e tudo mais!. (JOSÉ J. apud SILVEIRA, 2014, p. 14).

Em outro trecho do depoimento, há um aprofundamento analítico dessa reflexão:

Mas aqueles três meses, acho que foram significativos pra eu... pra toda a experiência que eu tive depois com bibliotecas. E é interessante que eu, eu inclusive cheguei a comentar isso com a Cleide ${ }^{6}$, que se eu não tivesse tido aquele tipo de experiência antes, o se não faz história né, mas eu fico pensando... pensando assim como minha história teria sido outra, melhor..., diferente, sei lá. Foram apenas três meses que fazem diferença na minha vida, e eu passei tantos anos

\footnotetext{
${ }^{6}$ Menção a uma amiga que hoje trabalha como bibliotecário na própria Luiz de Bessa.
} 
com medo de entrar naquele prédio (risos). (JOSÉ J. apud SILVEIRA, 2014, p. 5).

Reflexões que deixam transparecer na fala e nas reminiscências de nosso depoente o reconhecimento da Luiz de Bessa como importante pólo de enraizamento de suas experiências pessoais, sendo mais explicito, de ancoragem daqueles elementos que mobilizam seus referenciais identitários. Não por acaso José J. afirma ainda que:

Se hoje eu sou um profissional de política publica que pensa política publica tão contundentemente, parte dessa contundência veio das conclusões sobre o descaso do estado com a biblioteca publica Luiz de Bessa. Sabe um troço assim..., de parar um pouco e ver a experiência com a biblioteca refletir-se em outros campos da minha vida. E nesse sentido, a biblioteca foi referência das minhas inquietações com política pública; porque era um lugar que, quando eu vi a importância que as pessoas do interior davam eu pensava assim: "gente, porque que não há investimento continuado nessa biblioteca?" Sabe assim? [...] Essa relação vem sendo bastante (silêncio)..., é como se eu..., eu tivesse conhecido o prédio da biblioteca muito tarde (risos). Sabe, eu tinha uma relação com a Luiz de Bessa, com a instituição muito forte, mas com o prédio, o medo do prédio acho que foi vencido de 2000 pra cá, de 2002 pra cá. (JOSÉ J. apud SILVEIRA, 2014, p. 13-14).

Como pode ser observado, além do reconhecimento da importância que a Luiz de Bessa possui para a cidade e, em ampla medida, para o Estado, há uma explícita menção à forma como as experiências mantidas com a Biblioteca se reverberaram para outros campos da vida do entrevistado, principalmente nas lembranças do prédio e da Praça da Liberdade, e no modo como o mesmo pensa e atua no setor de políticas públicas. Reminiscências evocadas, em um primeiro momento, como algo que marcou negativamente o depoente, afastando-o da instituição, mas possibilitando a criação de um vínculo estreito com o carro-biblioteca, espaço no qual se formou enquanto leitor e pôde potencializar suas vocações literárias. No contexto biográfico de José J., a presença no carro constitui-se como referência determinante, inclusive, para o processo de redimensionamento de suas atuais perspectivas em relação à Luiz de Bessa e a outros espaços urbanos da capital mineira.

As experiências vivenciadas na e a partir da Luiz de Bessa também impactaram diretamente nos encaminhamentos que definiram os rumos da vida de nosso segundo interlocutor. Luiz R. nasceu em São José dos Campos, São Paulo, no ano de 1986 e veio para Belo Horizonte aos doze anos, onde mora com mais dois irmãos. Filho de pais leitores, acredita ter 
sido deles que herdou o gosto pela leitura. Aos cinco anos começou a ser alfabetizado pela irmã e passou a se interessar por diversos assuntos literários. Não escondia de ninguém sua predileção por textos e imagens relacionados ao universo automobilístico, embora portasse, ainda, uma segunda paixão: "eu gostava muito que meu pai ou minha avó contassem histórias para eu dormir, e disso aí, imagina, saiam histórias das mais variadas". (LUIZ R. apud SILVEIRA, 2014, p. 2).

Também tinha prazer em frequentar às bibliotecas das instituições em que estudou, "eu lembro até que eu vivia devendo multa de livro lá na biblioteca da escola, eles viviam me caçando - "você está devendo tanto aqui" -, pois eu deixava, eu esquecia de devolver". (LUIZ R. apud SILVEIRA, 2014, p. 3). Gosta e vai muito a teatros, exposições, museus e cinemas, só não se sente confortável em lugares muito tumultuados em razão da deficiência visual. Luiz $\mathrm{R}$. é portador de um problema congênito na retina e possui apenas $10 \%$ da visão, consegue andar sem o auxílio de bengala durante o dia, mas, à noite, não mostra a mesma desenvoltura para se locomover.

Tem uma afeição muito particular pela Praça da Liberdade, espaço que transita desde que chegou a Belo Horizonte. No entanto, não foi a Praça que o levou até à Luiz de Bessa. Esse contado só se deu quando o depoente já havia completado 22 anos e estava cursando o 50 período de Direito. À época, enfrentava dificuldades para ler os textos trabalhados em sala de aula e estava praticamente decidido a abandonar o curso. Vejamos o que ele diz:

Eu mesmo executava as tarefas da faculdade por mim mesmo, com meus olhos. Eu comecei a ver que, eu comecei a compreender que eu fazia isto com muita dificuldade porque até então eu não levava isso em conta, a dificuldade que eu tinha para ler os livros. Mas um belo dia a ficha caiu, eu tive uma epifania e falei "pera aí, isso daqui não dá pra mim, é muito esforço pra eu ficar lendo algo que as pessoas fazem com tanta facilidade e eu vou ficar aqui me esforçando tanto, eu vou ficar aqui me desgastando dez vezes mais, tendo que ler com o olho praticamente colado no papel, com luzes especiais e em uma posição inclinado para baixo que me deixava com dor nas costas?". O quê que aconteceu, neste período o meu curso ficou meio comprometido, eu não fui bem nas matérias, tomei bomba em algumas por causa disso, porque eu comecei a não conseguir estudar mais, eu comecei a criar resistência. Na hora em que eu ia estudar me dava uma resistência, eu ficava travado e eu comecei a me questionar: "o quê que eu vou fazer pra resolver isso?". Só que eu não sabia que existia um setor braille, eu não sabia o que era braille, eu não sabia o que era computador adaptado para deficiente visual, eu não sabia o que era lupa eletrônica, eu não sabia que existiam audiobooks em larga escala, eu não sabia que existiam pessoas que gravavam os livros para você. 
Eu nunca parei pra pensar nisso por que até então eu tive uma vida..., a minha vida foi conduzida como uma vida de uma pessoa que dispõe da integral visão. (LUIZ R. apud SILVEIRA, 2014, p. 5-6).

Tomou conhecimento da Biblioteca através do irmão, mas só teve coragem de se dirigir ao setor Braille passado um mês da primeira conversa sobre o assunto. Chegou lá se sentindo deslocado e achando aquilo tudo muito esquisito, mas mesmo assim marcou uma leitura voluntária para o dia seguinte. O que aconteceu? Vejamos o que ele nos diz:

É difícil essa readaptação, para mim foi muito difícil, em um dia eu estudo normalmente e no outro dia eu estou aqui para as pessoas lerem para mim? Ou seja, já tinha parte da minha autonomia tolhida, né!? Eu marquei voluntário, eu lembro até da primeira voluntária que leu para mim, ela se chamava Regina. Aquilo foi uma coisa esquisita, eu não consegui compreender bem o que ela leu, foi um estudo meio..., foi algo muito desconfortável, estranho, diferente, era o novo. Mas eu lembro que com uma semana eu já estava completamente adaptado com esta estrutura aqui, apaixonado com os voluntários daqui, muito integrado, me sentindo muito bem acolhido. (LUIZ R. apud SILVEIRA, 2014, p. 6-7).

Acolhimento e readaptação, ações integradoras que permitiram ao nosso entrevistado concluir o curso de graduação, passar em dois concursos públicos, aprender latim e criar vínculos afetivos estreitados por relações de sociabilidade mantidas tanto com os bibliotecários, quanto com os voluntários do setor. O depoente assim descreve a importância dessas novas relações estabelecidas no contexto da Luiz de Bessa:

Olha, eu não tenho, meu vocabulário não tem palavras para descrever como que é essa relação, de tão boa que ela é. Eu tenho grande parte dos meus amigos verdadeiros, amigos mesmo, eles vieram daqui. Com ralação aos bibliotecários, também são pessoas que eu vou levar no meu coração pelo resto da vida, são pessoas que fazem parte da minha história, eu poderia dizer assim. Eu sou muito grato à este setor, não só pela leitura que eu recebo, pela matéria que eu recebo, não só pela ajuda física que eu recebo mas também por saber que aqui é um lugar de pessoas especiais. O dia em que eu não puder mais frequentar este setor aqui, eu vou lembrar disso aqui como um belo, um período maravilhoso na minha vida, um período que eu posso dizer ajudou até na formação do meu caráter. As experiências, a maturidade que eu adquiri aqui, eu aprendi muita coisa neste setor aqui. Destes quatro anos e pouquinho que eu estou aqui, eu mudei muito como 
pessoa, eu amadureci demais, passei muita coisa graças às pessoas daqui, aprendi muita coisa, tive muita experiência. Eu devo, também, pouco do que eu sou a esse setor aqui. (LUIZ R. apud SILVEIRA, 2014, p. 7).

Incitado a falar um pouco mais sobre os tipos de relações constituídas por ele e as pessoas que dinamizam o setor Braille da Luiz de Bessa, e também sobre o modo como elas redimensionaram sua história de vida, o depoente continua sua narrativa:

Eu tenho o meu melhor amigo hoje, um dos meus melhores amigos, aqueles que a gente leva pra vida mesmo sabe?! Ele se chama Ângelo. Ângelo Ênio da Rocha Miranda, eu estou falando isso para poder ficar constado porque é uma pessoa muito especial na minha vida, ele é meu amigo, ele me ajuda em tudo o que eu preciso. É uma pessoa que eu frequento a casa dele, conheço a família dele, ele conhece o meu irmão. É uma relação absolutamente estreita. Tem o Gustavo, que eu fui padrinho de casamento dele que é outro amigo inseparável que está sempre na minha casa, é amigo meu e do meu irmão. E o pessoal deste balcão, eu passo aqui e tem a Andréia, a Adriana, a Judete, ali [no balcão] é como se eu estivesse conversando com os meus irmãos, é uma família isso aqui. É uma sensação de família, quando eu estou aqui eu sinto que estou na minha casa. Essa biblioteca aqui, eu olho para ela, essas mesas aqui, as cadeiras, os livros, é como se eu estivesse no sofá da minha casa com os meus livros e é muito gratificante estar aqui. Isso me emociona, falar disso me emociona por que eu gostaria de ter as palavras certas pra externar este sentimento, mas eu realmente não consigo. (LUIZ R. apud SILVEIRA, p.7).

Após um pequeno instante de silêncio, o depoente retoma sua narrativa e reforça ainda mais o lugar que a Biblioteca, o setor Braille e as pessoas com as quais passou a interagir ocupam hoje em sua vida. Como se verá, a Luiz de Bessa se tornou um pólo de enraizamento e uma referência com tamanha importância em sua história pessoal que Luiz R. deixa explícito o medo, o receio de que um dia não possa mais frequentar tal espaço:

Você já deve ter percebido que é algo muito importante pra mim esta biblioteca aqui. O dia que eu não puder mais vir aqui realmente vai ser lamentável, eu vou lembrar disso aqui com muito carinho e cada dia que eu venho aqui eu me sinto satisfeito por estar aqui, sabe! Igual eu te falei, hoje eu sou adaptado com computador e a lupa eletrônica, eu consigo ter certa autonomia para estudar e eu já dou conta de estudar 
sem o auxílio do voluntário, mas, neste período em que eu tinha 22 anos e no qual eu descobri o setor Braille, que eu ainda não estava adaptado, foi crucial porquê do sétimo período até o décimo os voluntários me carregaram no colo pra eu chegar até lá. E esses dois concursos que eu passei também foram graças à gentileza de todos os voluntários aqui. Se não fossem eles acho que eu ainda estaria lá no sexto período da faculdade ainda e não teria passado em concurso nenhum. (LUIZ R. apud SILVEIRA, p. 9).

Profusão de sensações que, somadas àquelas expressas no primeiro depoimento, nos permite assinalar alguns enquadramentos sociais e simbólicos responsáveis por conferir à Biblioteca Pública Estadual Luiz de Bessa o status de lugar de identidade e espaço de enraizamento. O primeiro deles indica que sua presença nas memórias e histórias de vida dos nossos depoentes está diretamente relacionada às representações que demarcam sua função de lugar de leitura, de educação, memória e sociabilidade. De fato, foi através dos acervos e atividades por ela dinamizados que nossos entrevistados conseguiram potencializar sua formação enquanto leitores, além de travarem contato com os dispositivos informacionais necessários à ampliação de seus universos culturais e educacionais, chegando mesmo a impactar em suas escolhas e perspectivas de atuação profissional.

Além de espaço de estudo e leitura, aparece de maneira recorrente na fala desses usuários uma compreensão de que a Biblioteca desempenha importante trabalho de conservação, organização e disseminação da memória, do patrimônio cultural e intelectual, bem como da história belo-horizontina, mineira e nacional. Percepção que não se institui tendo por referência apenas suas coleções especiais, uma vez que o próprio prédio insurge como substrato visível desse esforço mnêmico e preservacionista. Outro enquadramento marcante é aquele que apresenta a Luiz de Bessa como território de sociabilidade, um refúgio em meio à vida tumultuada da metrópole, onde se pode encontrar com os amigos e fazer novas amizades, descansar, ler um jornal, trocar ideias sobre uma exposição artística, tomar um cafezinho e compartilhar sonhos, desejos ou outras necessidades pessoais.

Nestes termos, através desses dois testemunhos nos tornamos capazes de evidenciar a importância intersubjetiva ocupada pela Luiz de Bessa no que diz respeito à composição do quadro representacional que modula as referências identitárias dos dois usuários aqui em foco, bem como indicarmos que tais referências possuem a capacidade de transcenderem o domínio individual, posto apontarem para um processo de validação coletiva dos seus distintos atributos e funções sociais. 


\section{Considerações finais}

Os depoimentos aqui apresentados sinalizam para um lugar muito demarcado que a Biblioteca Pública Estadual Luiz de Bessa ocupa na vida de nossos dois usuários. Em suas falas ela aparece referenciada, a um só tempo, como espaço onde a formação pessoal e intersubjetiva se mostrou potencializada, como arena onde a socialização e a relação com o outro, outras pessoas, outros pontos de ancoragem simbólica e afetiva possibilitou a definição de novos rumos para suas próprias vidas. Um território onde o acesso aos livros, à leitura e à informação acabou por se converter em esteio para que um deficiente visual conseguisse se formar em Direito, aprendesse latim e fosse aprovado em dois concursos públicos, assim como facultou que um sujeito vindo da periferia se projetasse como escritor e assumisse o cargo de consultor da Unesco para políticas públicas. Em síntese, um lugar onde as ações e experiências vivenciadas refletem diretamente na maneira como cada um delineia uma imagem de si e se apresenta para o mundo.

Por tanto, não é sem razão que Luiz R. e José J. se expressam em relação à Luiz de Bessa de maneira muito carinhosa, pontuando a importância dela em suas biografias e defendendo sua valorização social. Atitudes que só referendam nossa defesa de que as bibliotecas públicas são espaços mobilizadores de referenciais identitários. Mobilização que se mostra ancorada, sobretudo, nas experiências vivenciadas por cada sujeito em seu interior.

Sendo assim, eis aí algumas respostas possíveis para nossas duas questões iniciais: o que é e qual é a importância social/cultural das bibliotecas públicas no século XXI? As bibliotecas públicas são lugares de identidade e de enraizamento. Lugares de cultura e de socialização. Espaços de mediação informacional e de produção do conhecimento, cuja importância se faz melhor delineada quando, - e os depoimentos aqui colhidos corroboram para tal postulado -, passamos a apreendê-las como espaços vivenciais e de enraizamento, cujas ações práticas, aliadas à sua força simbólica, refletem as diferentes pulsões da vida social. Por isso a necessidade e a legitimidade de discussões e ações como as que tiveram lugar no seminário $A$ biblioteca pública no século XXI: lugar social, atuação política e estratégias de mobilização cultural.

\section{Referências}

BARATIN, Marc; JACOB, Christian (Org.). O poder das bibliotecas: a memória dos livros no ocidente. Rio de Janeiro: UFRJ, 2000.

BAUMAN, Zygmunt. Identidade. Entrevista concedida a Benedetto Vecchi. Rio de Janeiro: Jorge Zahar, 2005.

BOSI, Ecléa. Entrevista. Dispositiva, Belo Horizonte, v. 1, n. 2, p. 196199, nov. 2012/abr. 2013. Disponível em: <http://periodicos.pucminas.br/index.php/dispositiva/article/view/4301/4 454>. Acesso em: 09 fev. 2014. 
BOSI, Ecléa. Memória e sociedade: lembrança de velhos. 11. ed. São Paulo: Companhia das Letras, 2004.

BOSI, Ecléa. O tempo vivo da memória: ensaios de psicologia social. 2. ed. São Paulo: Ateliê, 2003.

BRIOSCHI, Lucila Reis; TRIGO, Maria Helena Bueno. Relatos de vida em ciências sociais: considerações metodológicas. Ciência e Cultura, v. 39, n. 7, 631-637, jul. 1987.

CESARINO, Maria Augusta da Nóbrega (Org.). Biblioteca pública estadual Luiz de Bessa: 50 anos de cultura. Belo Horizonte: Secretaria de Estado de Cultura de Belo Horizonte: Superintendência de bibliotecas públicas, 2006.

ELIAS, Norbert. A sociedade dos indivíduos. Rio de Janeiro: Jorge Zahar, 1994.

FERNÁNDEZ ABAD, Francisco Javier. Evolución histórica de la función social de las bibliotecas públicas. Revista General de Información y Documentación, n. 2, p. 93-110, 2006.

FRANÇA, Vera R. Veiga. Discurso de identidade, discurso de alteridade: a fala do outro. In: GUIMARÃES, César et al. Imagens do Brasil: modos de ver, modos de conviver. Belo Horizonte: Autêntica, 2002. p. 27-43.

FROCHTENGARTEN, Fernando. Memórias de vida, memórias de guerra: um estudo psicossocial sobre o desenraizamento. São Paulo: Perspectiva: FAPESP, 2005. (Estudos; 222).

GUARESCHI, Pedrinho; JOVCHELOVITCH, Sandra (Org.). Textos em representações sociais. 9. ed. Petrópolis: Vozes, 2007.

HALL, Stuart. A centralidade da cultura: notas sobre as revoluções culturais no nosso tempo. Educação \& Realidade, Rio Grande do Sul, v. 22, n. 2, p. 15-46, jul./dez. 1997.

HALL, Stuart. A diversidade cultural na pós-modernidade. 5. ed. Rio de Janeiro: DP\&A, 2001.

HALL, Stuart. Da diáspora: identidades e mediações culturais. Belo Horizonte: UFMG; Brasília: Representação da UNESCO no Brasil, 2003.

HALL, Stuart. Quem precisa da identidade? In: SILVA, Tomaz Tadeu da (Org.). Identidade e diferença: a perspectiva dos estudos culturais. 8. ed. Petrópolis: Vozes, 2008. p. 103-133.

JARAMILLO, Orlanda. La biblioteca pública, un lugar para la formación ciudadana: referentes metodológicos del proceso de investigación. Revista Interamericana de Bibliotecología, Medellín, v. 33, n. 2, p. 287-313, jul./dec. 2010.

JARAMILLO, Orlanda; MONTOYA RÍOS, Mónica. Revisión conceptual de la biblioteca pública. Revista Interamericana de Bibliotecología, Medelin, v. 23, n. 1-2, p. 13-56, ene/dic., 2000. 
JARAMILLO, Orlanda; MOTOYA R., Mónica; MONCADA P., Daniel. Biblioteca pública: descripción de una propuesta metodológica para la construcción de su historia. Revista Interamericana de Bibliotecología, Medelin, v. 28, n. 1, p. 169-186, ene./jun. 2005.

JODELET, Denise (Org.). As representações sociais. Rio de Janeiro: UERJ, 2001.

JODELET, Denise. Les représentations sociales dans le chanp de la culture. Social Science Information, Londres, v. 41, n. 1, p. 111-133, 2002.

MARTINS, Ana Amélia Lage. Mediação: reflexões no campo da Ciência da Informação. 2010. 255f. Dissertação (Mestrado em Ciência da Informação)-Escola de Ciência da Informação da Universidade Federal de Minas Gerais, Belo Horizonte, 2010.

MENESES TELLO, Felipe. Bibliotecas y sociedad: reflexiones desde uma perspectiva sociológica. Revista Interamericana de Bibliotecología, v. 28, n. 2, p. 117-133, jul./dic. 2005.

MOSCOVICI, Serge. Representações sociais: investigações em psicologia social. 4. ed. Petrópolis: Vozes, 2003.

MÜLLER, Suzana P. M. Biblioteca e sociedade: evolução da interpretação das funções e papéis da biblioteca. Revista da Escola de Biblioteconomia da UFMG, Belo Horizonte, v. 13, n. 1, p. 7-54, mar. 1984.

NORA, Pierre. Entre memória e história: a problemática dos lugares. Projeto História, São Paulo, n. 10, p.7-28, dez. 1993.

SILVA, Tomaz Tadeu da (Org.). Identidade e diferença: a perspectiva dos Estudos Culturais. 8. ed. Petrópolis: Vozes, 2008.

SILVEIRA, Fabrício José Nascimento da. Biblioteca pública, identidade e enraizamento: elaborações intersubjetivas ancoradas em torno da Luiz de Bessa. 2014. 252f. Tese (Doutorado em Ciência da Informação)-Escola de Ciência da Informação da Universidade Federal de Minas Gerais, Belo Horizonte, 2014.

SILVEIRA, Fabrício José Nascimento da. Biblioteca pública, memória e representações sociais: o depoimento de um grupo de usuários acerca da Mário de Andrade. Investigación Bibliotecológica, v. 26, n. 27, p. 199-231, mayo/ago. 2012. México. Disponível em: <http://www.scielo.org.mx/pdf/ib/v26n57/v26n57a7.pdf>. Acesso em: 06 set. 2013.

SILVEIRA, Fabrício José Nascimento da. Biblioteca, memória e discursos identitários: uma leitura sócio-histórica dos depoimentos colhidos pelo Projeto Memória Oral da Biblioteca Mário de Andrade (BMA). Tendências da Pesquisa Brasileira em Ciência da Informação, v. 5, n. 1, 2012, 23p. Disponível em: <http://inseer.ibict.br/ancib/index.php/tpbci/article/view/76/118>. Acesso em: 06 set. 2013. 
SILVEIRA, Fabrício José Nascimento da; REIS, Alcenir Soares dos. Biblioteca como lugar de práticas culturais: uma discussão sócio-histórica. Informação \& Sociedade: Estudos, João Pessoa, v. 21, n. 1, p. 37-54, jan./abr. 2011.

WEIL, Simone. A condição operária e outros estudos sobre a opressão. Seleção e apresentação de Ecléa Bosi. 2. ed. Rio de Janeiro: Paz e Terra, 1996.

WEIL, Simone. O enraizamento. Bauru: EDUSC, 2001. 